\title{
Making Progress on Understanding and Remedying Racial Profiling
}

\author{
KENT ROACH*
}

The editors of the Alberta Law Review are to be congratulated on their prescience in selecting the subject of racial profiling as a topic for a forum. The issue of profiling, specifically the use of stereotyped perceptions of race as a basis for heightened police scrutiny, has been very much in the news from coast to coast this past year. In Nova Scotia, a discrimination complaint made by the African-Canadian professional boxer Clayton (Kirk) Johnson arising from multiple stops by the Halifax police was upheld. 'The Ontario Human Rights Commission has released a report on racial profiling mainly in relation to the AfricanCanadian community. ${ }^{2}$ Profiling of Aboriginal people also remains an issue in Ontario and western Canada. Over a decade ago, the Manitoba Aboriginal Justice Inquiry concluded that J.J. Harper was stopped by the Winnipeg police with fatal consequences because he was Aboriginal. $^{3}$ In Saskatchewan, public inquiries are examining allegations of police misconduct with respect to Aboriginal people. Finally, the requirement that a Parliamentary committee begin a comprehensive inquiry into the operation of the Anti-terrorism $\mathrm{Act}^{4}$ by the end of 2004 raises the possibility that Parliament might re-visit its decisions not to include an anti-discrimination clause in that law or perhaps even enact a more specific provision against profiling on the basis of race and other prohibited grounds of discrimination.

The two articles featured in this forum are important additions by experienced and accomplished authors to the growing Canadian literature on the subject of racial profiling. ${ }^{5}$ They provide important insights into the complexities of the many issues surrounding profiling. Any response to either the existence or perception of profiling should involve not only the police, but also courts, legislatures, human rights commissions, and ultimately all of Canadian society. The profiling issue not only implicates the entire criminal justice system, but larger issues concerning the role of criminal law and equality in Canadian society.

Professor of Law, University of Toronto. I thank my colleague Sujit Choudhry for helpful comments on an earlier draft.

Johnson v. Halifax (Regional Municipality) Police Service [2003] N.S.H.R.B.I.D. No. 2 (QL).

Ontario, Paying the Price: The Human Cost of Racial Profiling (Inquiry Report) 2003, online: Ontario Human Rights Commission (OHRC) <www.ohrc.on.ca/english/consultations/racial-profiling-report. pdf $>$ [OHRC Report].

Manitoba, Report of the Aboriginal Justice Inquiry of Manitoba, vol. 2 (Winnipeg: Queens Printer, $1991)$ at 32.

S.C. 2001 c. 41.

See, for example, Sujit Choudhry, "Protecting Equality in the Face of Terror: Ethnic and Racial Profiling and Section 15 of the Charter" in Ronald Daniels, Patrick Macklem \& Kent Roach, The Security of Freedom: Essays on Canada 's Anti-Terrorism Bill (Toronto: University of Toronto Press, 2001) 367; David Tanovich, "Using the Charter to Stop Racial Profiling: The Development of an Equality-based Conception of Arbitrary Detention" (2002) 40 Osgoode Hall L.J. 145; Sujit Choudhry \& Kent Roach, "Racial and Ethnic Profiling: Statutory Discretion, Constitutional Remedies, and Democratic Accountability" (2003) 41 Osgoode Hall L.J. 1; and Reem Bahdi, "No Exit: Racial Profiling and Canada's War Against Terrorism" (2003) 41 Osgoode Hall L.J. 293. The Alberta Law Review intends to publish in a forthcoming issue a third article by Scot Wortley on the matter of racial profiling in Canada. 
Any debate about profiling that is not guided by a clear definition of profiling is bound to be a recipe for frustration and bitterness. The Ontario Human Rights Commission has recently defined profiling as "any action undertaken for reasons of safety, security or public protection that relies on stereotypes about race, colour, ethnicity, ancestry, religion, or place of origin rather than on reasonable suspicion, to single out an individual for greater scrutiny or different treatment." ${ }^{\circ}$ The Commission also notes that age and/or gender can influence the experience of profiling and that racial profiling can be distinguished from "criminal profiling which isn't based on stereotypes but rather relies on actual behaviour or on information about suspected activity by someone who meets the description of a specific individual."?

My colleague Sujit Choudhry and I have defined profiling as the use of race, religion, or ethnicity "either as the sole reason, or as one factor among many, in a decision to detain or arrest an individual, or to subject an individual to further investigation. Whether used as the sole factor, or one factor among many, profiling allows race, religion or ethnicity to play a determinative role in investigative decisions." ${ }^{8}$ Profiling allows distinctions to be drawn among otherwise identical persons on the basis of race or ethnicity. ${ }^{9}$ Especially to the extent that it involves stereotypes associating certain races and religions with particular crimes, profiling likely contravenes the guarantee of equality without discrimination under s. 15 of the Canadian Charter of Rights and Freedoms. ${ }^{10}$

Differing definitions of profiling may also explain some of the gaps between perceptions by minority communities and the media that profiling does occur and frequent albeit not universal denials by the policing community that it does not. The emphasis on effects-based discrimination under s. 15 of the Charter is a fundamental feature of modern understandings of equality rights, but it is still not widely accepted in popular understandings of racism, which are often tied to the idea of intentional discrimination. Work on the appropriate definition of profiling is a priority if there is to be a more constructive debate in the future and greater consensus about what is and is not appropriate.

Professor Tim Quigley of the University of Saskatchewan's College of Law examines profiling in the context of whether police have the power to detain people for investigative reasons when they do not have reasonable grounds to arrest a person for an offence. He focuses on the widely followed but controversial decision of the Court of Appeal for Ontario in R. v. Simpson, " which held that police could stop people on the basis of articulable cause or reasonable suspicion of involvement in crime.

It is notable that the Court of Appeal for Ontario in Simpson expressed concerns about discriminatory profiling. The Court held that there was no articulable cause that justified the

OHRC Report, supra note 2 at 6 [emphasis in original].

Ibid.

Choudhry \& Roach, supra note 5 at 2-3. This definition of profiling also excludes the use of race or ethnicity as a description of an individual suspect.

Roach \& Choudhry, Brief to the Special Senate Committee on Bill C-36, on file with the author.

Part I of the Constitution Act, 1982, being Schedule B to the Canada Act 1982 (U.K.), 1982, c. 11 [Charter]. See Choudhry, supra note 5.

(1993) 12 O.R. (3d) 182, 79 C.C.C. (3d) 482 [Simpson cited to C.C.C.]. 
stop and subsequent search of a young African-Canadian ${ }^{12}$ man who was seen emerging from a house in Toronto's Regent Park area that had been described in a police memorandum as a "crack house." The Court stressed that the subjective hunches of police officers were not enough to justify investigative detention. Justice Doherty stated that the requirement for:

an objectively discernible standard ... serves to avoid indiscriminate and discriminatory exercises of the police power. A "hunch" based entirely on intuition gained by experience cannot suffice, no matter how accurate that "hunch" might prove to be.

Such subjectively based assessments can too easily mask discriminatory conduct based on such irrelevant factors as the detainee's sex, colour, age, ethnic origin or sexual orientation. ${ }^{13}$

The subjective hunch of the police in Simpson turned out to be correct. After observing and touching a bulge in the accused's pocket, the police officer asked Mr. Simpson to remove the object, which turned out to be cocaine. The Court of Appeal held that this was an unreasonable search and excluded the cocaine, stating that the police officer's belief that they could detain and question all people who attended a residence that the police believed was the site of ongoing criminal activity was a "dangerous and erroneous perception of the reach of police powers" that "must be emphatically rejected" by the Court. ${ }^{14}$

Despite the Court's laudable concern about discriminatory profiling and their firm rejection of the police conduct in the case, Professor Quigley makes a strong and sophisticated argument that the extension of police powers in Simpson and its further extension by courts in subsequent cases will have a disproportionate effect on minorities. He points to American jurisprudence under Terry v. Ohio, ${ }^{15}$ which suggests that powers of investigative detention and search may be concentrated "in inner city neighbourhoods where the poor and minorities are more apt to live and frequent."16 Drawing on American scholarship, he argues that those who avoid or evade the police may do so for legitimate reasons that are unrelated to factual guilt. Professor Quigley's criticisms of investigative stops are similar to the Manitoba Aboriginal Justice Inquiry's conclusions that police officers should be restricted to existing arrest powers that allow a person to be stopped on the basis of reasonable and probable grounds that they have committed an offence. ${ }^{17}$

Professor Quigley also raises the fundamental point that the limits that courts place on investigative detention (or for that matter, arrest) will be under-enforced because "innocent

12 The race of the accused is not mentioned in the judgment, but was provided to me by David Tanovich. I am grateful for Professor Tanovich's assistance to me on this matter.

13 Simpson, supra note 11 at 501-502.

$14 \quad$ Ibid. at 507. The case thus constituted an exception to the reluctance of courts to exclude unconstitutionally obtained non-conscriptive evidence. More recently, see R. v. Buhay, [2003] I S.C.R 631 , (2003), 174 C.C.C. (3d) 97, deferring to a trial judge's decision to exclude evidence under s. 24(2) of the Charter in response to concerns about the conduct of the local police.

15 392 U.S. 1 (1968)

16. See, however, R. v. Griffiths (2003), 11 C.R. (6th) 136, 106 C.R.R. (2d) 139 (Ont. Sup. Ct. J.), as discussed in David M. Tanovich, "E-Racing Racial Profiling" (2004) 4l Alta. L. Rev. 905; and Tanovich, "R. v. Griffiths: Race and Arbitrary Detention" (2003) II C.R. (6th) 149.

17 Supra note 3 at 35. See also Tim Quigley, "Principled Reform of Criminal Procedure" in Don Stuart, R.J. Delisle \& Allan Manson, eds., Towards a Clear and Just Criminal Law: A Criminal Reports Forum (Toronto: Carswell, 1999) at 289 
people will rarely pursue a remedy and many of those who are factually guilty will simply plead guilty without litigating the constitutionality of the detention." 18 This raises the important issue of the inadequacy of s. 24(1) remedies to deal with instances of discriminatory profiling. ${ }^{19}$ One option would be for courts to use their newly confirmed powers to award advance costs in public interest litigation to allow claims of discriminatory profiling to be heard in civil courts. ${ }^{20}$ Courts can also re-think the question of the appropriate level of damages for the violation of Charter rights. The most frequently awarded quantum of damages for breach of a Charter right that does not cause consequential damages is $\$ 500 .{ }^{21}$ This is hardly a figure that will encourage individuals and lawyers to flock to civil courts to make claims based on profiling. Another barrier is the existence of short limitation periods to protect public authorities in a number of jurisdictions. Another possible reform would be to recognize that the criminal courts can reduce sentence $e^{22}$ or award costs ${ }^{23}$ or even damages as a means to deal with abuses in the investigative process that may not warrant a stay of proceedings or produce evidence that can be excluded. Such reforms would encourage one-stop shopping, but would only benefit those who were charged with an offence and who had that offence proceed to trial.

The costs and limits of the court system also points in the direction of complaints to human rights commissions and proactive inquiries by those commissions, as has recently occurred in both Nova Scotia and Ontario. Another possibility is the development of police complaints systems that will be receptive to complaints of discriminatory treatment. People who believe that they have suffered discrimination at the hands of the police are not likely to complain to the police, as is required in some jurisdictions. Some complaints systems incorporate a form of public interest standing that allows those not directly affected to make a complaint. ${ }^{24}$ Many police complaints systems make use of mediation. Some complainants of profiling have expressed a willingness to accept a genuine apology. ${ }^{25}$ Restorative circles and community meetings may have a role to play in mending the hard feelings that are sometimes caused by perceptions and allegations of profiling. At the same time, there needs to be a credible possibility of adjudication to deal with imbalances of power. Investigative reporting by the media and reports by civil society groups can also play a role in bringing attention to low-visibility police practices. It should not be assumed that the only effective remedy for racial profiling will be a strong judicial remedy.

18 Tim Quigley, "Brief Investigatory Detentions: A Critique of $R$. v. Simpson"(2004) 41 Alta. L. Rev. 935 at 948 .

Charter, supra note 10.

British Columbia (Minister of Forests) v. Okanagan Indian Band, [2003] 3 S.C.R. 371, (2003), 21

B.C.L.R. (4th) 209.

21 Crossman v. Canada, [1984] I F.C. 681, (1984), 9 D.L.R. (4th) 588 at 600 (T.D.); Lord v. Allison (1986), 3 B.C.L.R. (2d) 300 at 316, B.C.J. No. 3205 (QL) (S.C.); Chrispen v. Kalinowski (1997), 156 Sask. R. 58,117 C.C.C. (3d) 176 at 191 (Q.B.).

22 For a proposal that sentences be reduced as a remedy for unfair prison conditions, see Commission of Inquiry into Certain Events at the Prison for Women in Kingston (Ottawa: Public Works and Government Services Canada, 1996) at 183-85.

R. v. 974649 Ontario Inc., [2001] 3 S.C.R. 575, (2001), 159 C.C.C. (3d) 321.

Royal Canadian Mounted Police Act, R.S.C. 1985, c. R-10 (as amended), s. 45.35.

Kent Roach, Due Process and Victims' Rights: The New Law and Politics of Criminal Justice (Toronto: University of Toronto Press, 1999) at 224. 
Professor Quigley also raises an important point of institutional division of labour with his arguments that Parliament, as opposed to the courts, should create police powers. This is a compelling position associated with Brian Dickson's famed dissents in a number of police power cases. Justice Dickson's position was that Parliament should take responsibility for the expansion of police powers and that this would make both the extent of police powers and the duties of citizens clearer than if courts were to make such decisions in a piecemeal and retroactive fashion. ${ }^{26}$ Professor Quigley's argument against judicial expansion of police powers is also consistent with his advocacy for a better and more comprehensive codification of criminal procedure. ${ }^{27}$ Unfortunately, Parliament has neglected this project and relied on limited responses to specific court decisions. The result has been some expansion of police powers, but not in a way that has involved a discussion of first principles and wide public involvement and discussion.

Parliament has avoided the issue of profiling under the Criminal Code ${ }^{28}$ refusing either to ban or authorize it under the Anti-terrorism Act ${ }^{29}$ or the proposed Public Safety Act. ${ }^{30}$ Parliament's silence on this issue is troubling given that Canada's Arab and Muslim communities have expressed concerns about profiling in the wake of September 11 and because the precedent exists in Canada's Emergencies $A c t^{31}$ for Parliament to state that profiling is not acceptable, especially in crisis. The Emergencies Act demonstrates our ability to learn from past mistakes, such as the internment of Japanese Canadians during World War II. It serves as an inspiring aspiration to avoid stereotypes and fear in future times of crisis. It is regrettable that Parliament did not make such a commitment to non-discrimination at the time it enacted the Anti-terrorism Act.

The fact that the present Minister of Justice, Irwin Cotler, called for an anti-discrimination

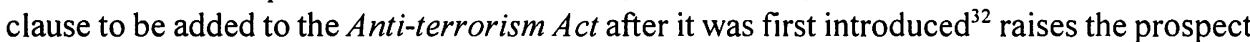
that Parliament might address this issue when it commences its three-year review of the terms and operation of the Anti-terrorism Act. Indeed, as Professor Tanovich of the University of Windsor notes in his article, there have been proposals to amend the Anti-terrorism Act to

26. Moore v. The Queen, [1979] I S.C.R. 195, (1978), 43 C.C.C. (2d) 83; Colet v. The Queen, [1981] 1 S.C.R. 2, (1981), 57 C.C.C. (2d) 105; Reference re Judicature Act (Alberta), s. 27(I), [1984] 2 S.C.R. 697 C.C.C. (3d) 466, sub nom. Wiretap Reference. Supra note 17.

R.S.C. 1985 , c. C-45

Supra note 4.

Bill C-7, An Act in respect of criminal justice for young persons and to amend and repeal other Acts, 3rd Sess., 37th Parl., 2004.

31 Section 4(b) of the Emergencies Act, S.C. 1988, c. 29 provides that: "Nothing in this Act shall be construed or applied so as to confer on the Governor in Council the power to make orders or regulations ... (b) providing for the detention, imprisonment or internment of Canadian citizens or permanent residents as defined in the Immigration Act on the basis of race, national or ethnic origin, colour, religion, sex, age or mental or physical disability."

32 Professor Cotler, then a backbencher, wrote

There is a potential in the expansive powers of the Act for possible singling out of visible minorities for differential treatment. The inclusion of a non-discrimination clause respecting the application of the Act in matters of arrest, detention and imprisonment would have important as well as substantive value. Such a provision now exists in section 4(b) of the Emergencies Act ... and it would seem desirable to include such a provision in this bill.

Irwin Cotler, "Thinking Outside the Box: Foundational Principles for a Counter-Terrorism Law and Policy" in Daniels, Macklem \& Roach, supra note 5, 111 at 128. 
place a general provision in the Criminal Code that would define and prohibit discriminatory profiling in the enforcement of any of its provisions. Professor Choudhry and I proposed the following to the Senate Committee on Bill C-36:

\section{Racial and Ethnic Profiling Definitions}

1. "racial and ethnic profiling" means the practice of a law enforcement agent relying, to any degree, on race, ethnicity, or national origin in selecting which individuals to subject to investigation or heightened scrutiny.

"law enforcement agent" includes any peace officer or person exercising law enforcement power under federal legislation;

"law enforcement agency" includes the Royal Canadian Mounted Police, Canadian Customs, the Canadian Security Intelligence Service, and other police forces exercising powers under ss. 82.28 and 83.3 ;

Ban on Racial and Ethnic Profiling

2. (a) No law enforcement agent or law enforcement agency shall engage in racial and ethnic profiling.

(b) Racial and ethnic profiling does not include reliance on race, ethnicity or national origin in combination with other identifying factors when the law enforcement agent is seeking to apprehend a specific suspect whose race, ethnicity, or national origin is part of the description of the suspect.

\section{Enforcement}

3. A finding that a law enforcement agent or law enforcement agency has engaged in racial and ethnic profiling shall allow a court to award any remedy that is appropriate and just in the circumstances including damages, injunctions, declarations and costs. In addition to the award of remedies, the court may also refer the matter to a human rights commission that has jurisdiction with respect to the particular law enforcement agent or law enforcement agency.

\section{Data Collection}

4. The Attorney General of Canada shall prepare and cause to be laid before Parliament and the Attorney General of every province shall publish or otherwise make available to the public an annual report on racial profiling for the previous year. The report shall include:

(a) Any steps taken to ensure that law enforcement officers and law enforcement agencies not engage in racial and ethnic profiling;

(b) Data on enforcement practices that is sufficiently detailed to determine whether law enforcement agencies are engaged in racial and ethnic profiling; and 
(c) Reports made under s. 83.31 shall, subject to the exceptions in s. 83.31(4)(a)-(c), include information on the racial and ethnic origins of those subjected to investigative hearings under s. 83.28 and preventive arrests under s. $83.3 .^{33}$.

This proposal was prepared under considerable time constraints and draws heavily on American developments, including the proposed federal The End Racial Profiling Act of $2001 .^{34}$ The American proposal had bi-partisan support before the terrorist attacks of September 11,2001, but has lost momentum since that time. There is a chance, however, that a similar or improved provision could be added to Canada's Criminal Code as a result of the Parliamentary review of the Anti-terrorism Act.

To be sure, such a proposal would be complicated and the above proposal could probably be improved. The forms of profiling that would be prohibited would have to be defined with precision. Section 2(b) of our proposal should respond to concerns that race and ethnicity could not be used to describe individual suspects. There would also be federalism issues, as such a Criminal Code amendment might mandate that provincial and municipal police forces keep information and develop policies on profiling. At the same time, it should be noted that the Anti-terrorism Act already includes provisions requiring provincial reporting on the use of preventive arrests and investigative hearings. ${ }^{35}$ There would also be difficult issues about whether a Criminal Code amendment could empower courts to award damages, costs, injunctions, declarations, or other remedies should they find that discriminatory profiling occurs, as is contemplated under section 3 of our proposal. The addition of an explicit power to reduce sentences as a remedy for profiling might also be contentious and not assist factually innocent victims of profiling. Some might find our proposal to be too soft; others may find it to be too tough. Some might argue that profiling itself should be a crime in a manner similar to unlawful invasion of privacy. Others might argue that following the approach taken under human rights legislation, the focus should be on providing remedies for profiling.

There are other possible reforms even if Parliament does not have an appetite for a ban on racial profiling. One alternative would be the non-discrimination clause proposed by Irwin Cotler. Such a clause would mainly have a symbolic value in stating that discriminatory profiling was wrong. It would balance the emphasis in the Anti-terrorism Act on enhanced hate crimes with a statement that discrimination is wrong, whether committed by private or public actors. Given considerable support in some quarters of the public for profiling in the wake of September 11, the value of even a symbolic affirmation of non-discrimination should not be dismissed out of hand. Parliament could follow Professor Tanovich's proposal of imposing a burden on the state to prove a non-discriminatory justification for an investigative stop. Professor Tanovich's proposals would primarily affect the subset of cases that reach court while Professor Cotler's proposal would speak more to society at large by re-affirming Canada's commitment to non-discrimination. The fight against discrimination should be fought both in court and in society at large.

35 Criminal Code, supra note 28, s. 83.31. See also s. 25.3(1), requiring provincial police to prepare annual reports on activities that would otherwise be illegal. 
Professor Tanovich's article in this forum builds on his past and ongoing research on racial profiling in Canada. A particular strength of his research is its comparative focus, as he draws on experiences in both the United States and the United Kingdom with racial profiling and attempts to govern investigative stops by the police. Canadians in particular need to pay more attention to the experience in the United Kingdom, which includes both statements of non-discrimination principles and the collection of data. Profiling is not simply an American issue.

Professor Tanovich also is absolutely correct to relate the issue of profiling to the style of policing. As he argues, profiling is less likely to occur in "crime-solving or reactive policing" and more likely to occur in "proactive policing" - particularly policing focused on drugs. In a comparative study of policing in Niagara Falls, New York and Niagara Falls, Ontario in the early 1990s, my colleague Marty Friedland and I found striking differences in policing styles on both sides of the border. The American police were much more proactive in part because they had many more police officers patrolling the streets, particularly in the peak late evening period. ${ }^{36}$ The police on the Canadian side were more thinly stretched and spent much more of their time responding to calls, especially false burglar alarms. Although we did not attempt to measure profiling at the time, my sense was that the proactive and often in-yourface style of policing on the American side would likely result in more profiling, as well as friction between the police and the community.

We need to examine the issue of profiling in the larger context of policing styles and of what we expect of the police. When we ask the police proactively to respond to problems, such as drugs, guns, terrorism, street crime, and what used to be called vagrancy, we may also be increasing the risk of tense relations between police and minority communities. These issues are also related to the extent of our reliance on the criminal law. It is an interesting question whether the proposed decriminalization of marijuana possession will change police behaviour. Similarly, some anti-terrorism strategies may increase the risk of discriminatory profiling while other strategies, such as screening all passengers for weapons and explosives, may decrease the risk. ${ }^{37}$

Profiling is also linked to larger and sensitive issues about crime. Profiling may in part be a response, however misguided, to crime problems that may have disproportionate effects on particular communities. At the same time, ill-will between the police and the community that may be produced by profiling may have a negative impact on the co-operation that the police receive from minority communities. In my experience, one of the more effective arguments against profiling, especially in the wake of September 11, has been to argue that it is not only wrong, but that it is counter-productive in responding to crime. Profiling is not only over- and under-inclusive, but it may threaten much needed co-operation between the police and minority communities. In any event, we cannot afford to view profiling in isolation from the tasks that we give our police and our criminal law.

36. Kent Roach \& M.L. Friedland, "Borderline Justice: Policing in the Two Niagaras" (1996) 23 Am. J. Crim. L. 241.

37 For arguments that increased reliance on administrative law and technology may impose less of a threat to equality, see Kent Roach, September 11: Consequences for Canada (Montreal: McGill-Queens Press, 2003), c. 4 and c. 7. 
Professor Tanovich also makes the point that "profiling is a self-fulfilling prophecy. The more a group is targeted the greater the likelihood that criminality will be discovered particularly for those offences that are prevalent in society such as drug use." 38 This raises the broader issue of systemic discrimination throughout the criminal justice system and the overrepresentation of Aboriginal and African-Canadian people in prisons. Initiatives to stop profiling can be seen as addressing this issue at the front-end of the criminal process while sentencing initiatives, such as those undertaken under s. 718.2(e) of the Criminal Code, can be seen as back-end reforms. ${ }^{39}$ Back-end reforms have been controversial and so far have not been very successful in reducing overrepresentation. This suggests that front-end reforms are extremely important. Front-end reforms include matters such as more restrained use of the criminal sanction, crime prevention programs, pre-charge screening, bail reform, diversion, and anti-profiling initiatives.

Profiling needs to be addressed and placed in the larger context of the role of the criminal law and equality in Canadian society. The articles in this forum advance the debate about profiling in Canada and deserve to be widely read.

Section 718.2 (e) provides that "all available sanctions other than imprisonment that are reasonable in the circumstances should be considered for all offenders, with particular attention to the circumstances of aboriginal offenders." The last phrase has been controversial. For criticisms of its focus on Aboriginal offenders, see Philip Stenning \& Julian V. Roberts, "Empty Promises: Parliament, the Supreme Court, and the Sentencing of Aboriginal Offenders" (2001) 64 Sask. L. Rev.137. For replies to this article, see "Forum" (2002) 65 Sask. L. Rev. Iff. 